\title{
Sustainability of Sheep and Goat Production Systems
}

\author{
Mariangela Caroprese, Marzia Albenzio, and Agostino Sevi
}

\begin{abstract}
Sustainability of sheep and goat production systems has been investigated in this chapter in terms of environmental, social, and economic sustainability. Strategies to reduce waste from animal husbandry activities and the negative impact of animal husbandry on environment have been described. Social sustainability has been analyzed in relation to animal welfare and human-animal relationship. Economic sustainability of sheep and goat production systems in the Mediterranean countries has been addressed in terms of animal management plans to improve animal health, quality of products, and increase profitability of animal production systems. In particular, strategies to change the basic standard for sheep and goat productions into high standard of nutritional, hygienic, and technological quality have been analyzed.
\end{abstract}

\section{Introduction}

Sustainable development aims to meet human needs by preserving the natural environment so that these needs can be met both in the present and in the future (Peacock and Sherman 2010). The field of sustainable development can be divided into three concepts: environmental, social, and economic sustainability.

Environmental sustainability is linked to energy use, biodiversity and genetic conservation, and environmental management; when applied to farm animals, environmental sustainability is associated to the negative impact of husbandry on air, soil, and water pollution. Waste from animal husbandry comprises fecal and urinary output, and production of fermentation and respiration gases, such as carbon dioxide $\left(\mathrm{CO}_{2}\right)$ and methane $\left(\mathrm{CH}_{4}\right)$. In the waste usually high amounts of water, nitrogen $(\mathrm{N})$, and other inorganic molecules are found.

The link between animal production and natural environment is acquiring more importance for the sustainability of the farm system (de Rancourt et al. 2006).

M. Caroprese $(\bowtie) \bullet$ M. Albenzio • A. Sevi

Department of the Sciences of Agriculture, Food and Environment (SAFE), University of

Foggia, Via Napoli 25, 71122 Foggia, Italy

e-mail: mariangela.caroprese@unifg.it 
Consumer concerns about the quality and sustainability, including ethical aspects, of the production cycle of animal food products is increasing. Social sustainability concerns politics, social institution, culture, tradition, and civil society. In this chapter social sustainability is discussed as animal welfare and human-animal relationship. In particular, the concerns about life quality of farm animal in relation to human-animal relationship to optimize animal production are presented.

In the Mediterranean area small ruminant farming systems represent one of the most important agricultural activity connected to the utilization of marginal lands, with prevalence of pastoral system, low level of mechanization, and production of typical products, mainly cheeses. Although small ruminant farming systems are largely diffused in all the Mediterranean countries, the level of animal management is far from an acceptable level of animal health, quality of products, and profitability.

\subsection{Environmental Sustainability of Sheep and Goat Production System}

Ruminant livestock produce about 80 million tons of methane $\left(\mathrm{CH}_{4}\right)$ accounting for about $28 \%$ of anthropomorphic emissions each year (Beauchemin et al. 2008). $\mathrm{CH}_{4}$ is physiologically produced as a by-product of digestion; at farm level $\mathrm{CH}_{4}$ is emitted both from direct ruminant fermentation and from manure. Methane production by ruminants is influenced by animal size, dry matter intake, carbohydrates, and other components of the diet (Wilkerson et al. 1994). The increasing level of concentrate in the diet of ruminants causes changes in the fermented substrate from fiber to starch and a decline in ruminant $\mathrm{pH}$ with a reduction of the proportion of dietary energy converted to $\mathrm{CH}_{4}$. However, the increased level of concentrate in ruminant diet should be limited at $50 \%$ of the diet to avoid negative effects on milk quality. A number of nutritional management strategies to reduce enteric $\mathrm{CH}_{4}$ production have been reported, among which are increasing the level of grain and lipids, and supplementation with ionophores in the diet. Furthermore, a number of feeding strategies to reduce $\mathrm{CH}_{4}$ emissions in animal production systems have been proposed, such as feeding maize and cereal silages instead of grass silage, improved pasture management, inclusion of legumes, yeast and enzyme, feed additives, or plants characterized by secondary compounds with potential $\mathrm{CH}_{4}$ suppressing properties (Beauchemin et al. 2008).

Nitrogen losses originate mainly from the imbalance and the asynchrony between the rate at which carbohydrates and proteins are degraded at rumen level (Tamminga 1996). The imbalance between the simultaneous availability of net energy and amino acids in the rumen is the main cause for $\mathrm{NH}_{3}$ ruminal losses; ammonia, after its conversion into urea in the liver, is found in blood and milk, and is excreted in urine. Apart from the contradictory results on the relationship between $\mathrm{CP}$ level of diet and milk yield and composition, the concentration of 
urea in the milk is always regarded as a good indicator of efficient use of dietary protein by the animals, and it is currently used to evaluate and to adjust the diet (Cannas 2002). The efficiency of dietary $\mathrm{N}$ utilization for milk protein synthesis is rather low in dairy sheep and goat (15-35\%) (NRC 1988), and the use of high protein level diets for sustaining milk production in lactating animals is widely studied. High protein level diet can result in a number of deleterious events: reducing environmental sustainability of sheep and goat farming, causing an increase of $\mathrm{N}$ output to the environment, and high levels of ammonia pollution in animal houses, which originates from animals' urine and feces and can be injurious to both livestock and stock persons' health. An increased $\mathrm{N}$ excretion in urine and feces, as a consequence of poor dietary $\mathrm{N}$ absorption, can result also in high growth of microorganisms. Sevi et al. $(1999,2006)$ suggest that the efficiency of utilization of dietary $\mathrm{N}$ in the lactating ewe increases with decreasing protein levels in the diet from 16 to $13 \%$, especially when limiting amino acids (lysine and methionine) in the ration are encapsulated to prevent bacterial deamination in the rumen. Sheep fed with a moderate protein level excrete more $\mathrm{N}$ than sheep fed with low protein level of the diet. On the contrary, the low protein level of the diet results in lower amount of feces, in less wet feces, and in higher $\mathrm{NH}_{3}$ release in the urine. The choice of a proper ventilation regimen in small ruminant housing is critical for the control of environment and for removing aerial pollutants, which originate from animals and their excreta. In particular, low ventilation rates can fail in removing efficiently the moisture and gases, which originate from the respiratory activity of animals and the decomposition and fermentation of manure, resulting in increased relative humidity and higher air concentrations of ammonia and carbon dioxide. Very high ventilation rates, instead, can result in higher air dust concentrations, probably due to reduced humidity levels and to turbulent air currents maintaining dust particles suspended in the air for a longer time. Ventilation rate is based on the length of ventilation cycles and on air speed. During summer, dairy sheep need an average ventilation rate of about $65 \mathrm{~m}^{3} / \mathrm{h} /$ head achieved by giving most ventilation cycles during the hottest hours of the day (Sevi et al. 2002, 2003b). However, also overnight air exchange for removing gases, mostly ammonia, originated from excreta decomposition and fermentation are of great importance. Furthermore, combining a moderate protein level of the diet $(16 \%)$ with low ventilation rates result in excretion of 40-64\% of higher volumes of urine and 40-79\% greater amounts of total water.

Litter management by using paraformaldehyde and bentonite is an effective strategy for reducing emissions from manure. Paraformaldehyde is a polyoxymethylene containing 90 to $98 \%$ formaldehyde, which has a recognized bacteriostatic effect on the microorganisms naturally present in droppings. Litter treatment with paraformaldehyde was shown to influence milk hygienic quality reducing somatic cell count and microbial cell load of 10 and $15 \%$, respectively. The use of paraformaldehyde for litter disinfection markedly increased protein $(10 \%)$ and fat $(20 \%)$ content in sheep milk with a consequent improvement of milk coagulation performance. Addition of paraformaldehyde to the bedding is a procedure that may be applied at intervals suitably far apart to be not economically prohibitive. Its use, however, would remain limited to circumstances in which there are difficulties in processing or marketing milk of low hygienic quality which could 
not be easily resolved using other cheaper methods (Sevi et al. 2000). In a subsequent study (Sevi et al. 2003a), the effects of litter renewal intervals on the yield and quality of ewe milk were evaluated as an alternative strategy to litter treatment with antimicrobial products. Bentonite has been used to reduce the levels of airborne particulates in livestock housing and improve the hygienic quality of ewe milk. Bentonite is mainly composed of clay minerals and has a high waterabsorbing capacity. It is relatively inexpensive and there are no reports of it having adverse effects on the health of either ewes or people. Litter renewal of litter at 4 weeks intervals can sustain health status of the mammary gland and improve ewe performance at the same levels as litter treatment with bentonite.

\subsection{Livestock Sustainability: Human-Animal Relationship and Sheep and Goat Welfare}

During the second half of the 20th Century, in the industrialized nations, production of meat increased; the increase regarded mainly poultry and pig production systems fed on grain and concentrated diets. The increase was less pronounced in sheep and goat production. In the developing countries production of bovine meat and sheep and goat meat increased more than threefold from 1961 to 2001 (Fraser 2008). The increased production was characterized by an increase in the number of animals and in a reduced number of farms rather than in an increase in the number of farms. In the industrialized countries, these events coincided with a cultural change in the way of looking at farm animal particularly on confinement production system. Such concern was addressed to preserve animal welfare by a scientific approach to the matter. In intensive production systems of sheep and goats, a number of researches have been conducted to define technical parameters in animal housing to control their impact on animal welfare and production (Sevi et al. 2009). Stocking density is a critical factor in sheep and goat housing because space allocation is known to affect both the performance and welfare of livestock. Space allowance reduction from 2 to $1 \mathrm{~m}^{2} /$ head showed interesting effects on feeding behavior in goats. In horned goats, a reduction of feeding activity and of resting time is found; a slighter reduction of the same parameters in goats without horns is observed (Loretz et al. 2004). In ewes confined in a space allowance of $1.5 \mathrm{~m}^{2} /$ head, a reduced humoral immune response is observed compared with ewes housed at a space allowance of $3 \mathrm{~m}^{2} /$ head. Furthermore, ewes that have free access to an outdoor area display an increased cell mediated immune response compared with ewes enclosed indoor (Caroprese et al. 2009).

Among structural housing parameters in sheep and goat buildings, inadequate airspace may be a limitation to high efficiency of production and good health in farmed livestock. This could be of practical interest when sheep are raised in warm climates and do not benefit from efficient ventilation system. Ventilation regimen, indeed, has a main role in sustaining the welfare by affecting thermal exchanges 
between the animal's body surface. With a pending high heat load situation, a moderate ventilation rate $\left(65 \mathrm{~m}^{3} / \mathrm{h}\right.$ per ewe $)$ improves the well-being of the lactating ewe compared to a low ventilation rate $\left(35 \mathrm{~m}^{3} / \mathrm{h}\right.$ per ewe), as suggested by behavioral, endocrine, and immune indicators. Under such conditions, a fan ventilation system, programmed to operate over upper critical air temperature $\left(30{ }^{\circ} \mathrm{C}\right)$ and relative humidity ( $70 \%$ ), has been proved to be economically unattractive, because it involves about a threefold greater energy cost and does not lead to remarkable improvements of ewe welfare and productivity compared to a moderate ventilation regimen $\left(65 \mathrm{~m}^{3} / \mathrm{h}\right.$ per ewe) (Sevi et al. 2002). Under heat stress, feed intake decreases especially when sheep are fed on low quality feed due to both the effort of reducing heat production and the slower feed transit through the digestive tract (Costa et al. 1992). Feed administration in late afternoon is beneficial in minimizing the impact of thermal stress on ewes' immune function and udder health (Sevi et al. 2001a).

One of the main factors in influencing the welfare of an animal is the quality of the human-animal relationship. A poor human-animal relationship can lead to chronic fear of humans and to handling difficulties, injury, and stress and, as a consequence to impaired growth, reproductive performance, and product quality (Hemsworth and Coleman 1998; Jones 1997). The nature and frequency of the relationship are different in sheep and goat farming system according to the management system, i.e., shepherding, intensive system, extensive systems. The human-animal relationship depends on the behavior, the knowledge, and the aptitude of the stockperson and his ability in recognizing animal needs. Frequent interaction between the animal and the stockman with repeated animal manipulation is a potential stress factor for sheep and goats. It is considered that sheep and goats are rustic animals; as a consequence, usually stockman handle them roughly, especially those with less experience or aptitude. On the contrary, it is well known that small ruminants have ancestral predatory fear, a gregarious nature, and a difficulty of adaptation to unfamiliar environments and integration with unknown groups. As a result, sheep and goat suffer if handling is excessive or inappropriate when rearing practices change suddenly or when regrouping and relocation occur suddenly or frequently (Sevi et al. 2001b). In lactating ewes, member exchange among groups increases aggression and altered immune response; also relocation results in a reduced immune response. An useful tool to minimize the stress related to artificial rearing is gentling, a friendly approach of the stockman towards the newborn animal. Several studies have highlighted that gentling strongly encourages the lamb and the kid reared without their mothers to positively interact with the stockman, whereas gentling has no beneficial effects on dam-reared animals. In artificially reared lambs, gentling improves their immune reactivity, making it comparable to that of dam-suckled lambs and reduced their plasma cortisol responses to handling (Caroprese et al. 2006). The genetic predisposition may play an important role in building positive human-animal relationship, and lamb gentling results in an improvement in the quality of human-animal relationship particularly in more reactive breeds. In particular, breeds that are more sensitive to disturbance by human handling more promptly build a positive relationship with 
humans possible because a higher disturbance generates a need to be reassured through social support (Caroprese et al. 2012).

The results obtained from these and other studies were used to regulate, manly in the European Union, a number of laws regarding production systems, transport, and slaughter of sheep and goat reinforced by EU directives. More recent evolution focused on voluntary certification of animal welfare to achieve standard of production recognized by retails and suppliers.

\subsection{Economic Perspectives of Sustainable Sheep and Goat Farming}

In the last 30 years, a progressive decline of the traditional pastoral system based on transhumance has been observed (Manrique et al. 1996). As a consequence of the decrease in rural populations and in traditional farming systems, sheep and goat livestock systems need to be changed to improve animal welfare, and to increase the animal productive efficiency, and food quality with particular regard to food safety (Gibon et al. 1999; Ronchi and Nardone 2003).

The reduction of veterinary costs linked to the enhanced animal health status and the increase of biological efficiency in terms of quantity and quality of milk and meat production can be considered as the strategies to improve the economic profits of a sustainable sheep and goat production. Veterinary and particularly parasitic diseases are one of the most important issues affecting health management in extensive small ruminant breeding being responsible of productivity losses. Infections can be considered deleterious for sheep and goat welfare and productivity, increasing mortality, management costs, and requirements for the use of anthelmintics. A sanitary program aiming to reduction of drugs requires high standard of welfare of animals and adequate management practices to improve farmers' income.

The need for increasing flock profits conforming to the quality standards is dependent on husbandry systems aiming to improve small ruminant welfare and health animal status. Extensive farming has proved to be beneficial to the welfare needs of lactating ewes but exposure to climatic extremes and seasonal fluctuations of pasture can threaten the welfare of extensively managed flocks. The gradual diffusion of semi-intensive husbandry systems led to the increase in highly productive dairy breeds. In this perspective, the maintenance of high standard of welfare of animals can markedly improve their biological efficiency. Under more intensive farming conditions, sheep and goats' welfare is influenced by the microenvironment control, the choice of proper housing, and building conditions to avoid crowding, aggressive behavior, increased ambient pollution, and poor animal health.

Farm management and health status of sheep and goat are mainly responsible for the quality of animal-based food products. Sheep and goat husbandry is strictly 
associated with rural societies contributing to the manufacture of local typical products which are expression of the regional cultural tradition.

Although products from small ruminants are intended to be free of chemical contaminants, the basic standard for sheep and goat productions lack high standard of nutritional, hygienic, and technological quality. Milk must have a desirable chemical composition and must be of satisfactory hygienic quality. This is essential in relation to public health, the suitability of milk for processing, and the quality of milk products. The health of the udder can have a profound effect on the quality and processing characteristics of milk. The most widely used indicator of udder health is somatic cell count (SCC), a measure of the number of white blood cells, known as leucocytes in milk. An elevated SCC usually indicates the presence of mastitis. Mastitis is caused by pathogenic bacteria entering the mammary gland via the teat canal and multiplying within the udder sinuses or epithelia or in the teat duct. Mammary inflammation during mastitis causes a range of physical, microbiological, and chemical changes in milk. The microorganisms found in raw milk may come from several sources: organisms from the udder, the environment (e.g., water, soil), milking equipment, bulk milk storage tank, tank in processing plant (FajardoLira and Nielsen 1998).

In the Mediterranean area, due to the reproductive seasonality of sheep, ewes are usually in their later stage of lactation in late spring and summer. Lactation is thus often shortened given that dairy factories stop collecting milk from farms since it is produced in smaller amounts and its coagulating behavior is deteriorated. Indeed, a number of events can occur in summer, which have a deleterious effect on coagulating properties of sheep milk and, namely, (1) the use of fat and nitrogen reserves to supply energy through gluconeogenesis at the expense of the mammary gland (Amaral-Phillips et al. 1993), (2) a plasma mineral imbalance, especially due to a reduction in sodium, potassium, calcium, and phosphorus and to an increase in chloride concentrations (Kume et al. 1987), (3) an increased milk pH, due to high amounts of $\mathrm{CO}_{2}$ dissipated via the panting (Habeeb et al. 1992), (4) an increased plasmin (PL) activity, the main endogenous proteinase in milk (Bianchi et al. 2004), (5) an increased bacterial load in milk, due to enhanced multiplication and growth of microorganisms in the litter (Sevi et al. 2001a). A worsening in milk coagulating behavior in ewes reared in pens without shading areas and receiving feed during the warmest part of the day has been observed (Sevi et al. 2001a). Under moderate heat stress, also a low ventilation rate has deleterious effects on milk yield and on clotting properties of milk (Sevi et al. 2003c). When collected for cheese making, the bulk milk from ewes in less ventilated houses has higher microbial load and somatic cell count compared to milk from ewes in more ventilated houses. As a result, a weaker caseous matrix of the curd releasing higher concentration of fat and protein in the whey was observed (Albenzio et al. 2005).

Profitability of dairy farms largely depends on milk casein content and milk hygienic quality in terms of pathogen, spoilage bacteria, and somatic cell count, giving that sheep and goat milk is almost totally destined for cheese making as raw milk. Milk yield and casein content increased to around $10 \%$, as well as the coagulation properties of milk $(+8 \%)$ when ewes are housed with a space allocation 
of $2 \mathrm{~m}^{2}$ per animal (Sevi et al. 1999). A stocking density of $1 \mathrm{~m}^{2}$ per ewe has deleterious effects on the hygienic quality of milk. Higher levels of airborne microorganisms also affected the mammary system of the animals with higher microbial cell loads and somatic cell counts being recorded in milk from ewes housed under high stocking density conditions. Milk produced by high densely stocked ewes, which are housed on a straw litter treated with bentonite, displayed lower concentrations of bacteria in their milk together with lower airborne microorganism loads. An increase of milk yield (3\%), of milk fat (10\%) and casein content $(5 \%)$, and of milk clotting time $(8 \%)$ was recorded. When no litter treatment is used, higher SCC $(+40 \%)$ was found in milk due to greater bacterial colonization of the udder. Adequate airspace allocation of $7 \mathrm{~m}^{3} /$ animal leads to increase in milk yield (20\%) and milk casein content (10\%) and improves renneting ability and hygienic quality of milk mainly in terms of somatic cell count $(-10 \%)$ (Sevi et al. 2001c).

Protein supplementation in grazing dairy ewes is a popular strategy for upgrading sheep nutrition in order to reduce the variability and improve ewe milk yield and composition. Feeding strategies together with several other management practices may improve the overall quality of milk for cheese making. Bulk milk produced by the ewes receiving a low crude protein diet $(13 \%)$ displayed higher casein $(10 \%)$ and low urea contents $(-20 \%)$. Therefore, the choice of a proper dietary crude protein level plays a main role in sustaining protein synthesis in the mammary gland (Sevi et al. 2006). The use of appropriate supplements in the diet of small ruminants can succeed in improving the nutritional features of animal-based food. This goal besides adding functional properties to animal-based food can meet the recently growing consumer demand both for quality food products and more ethical food production. Adequate supplementations in the diet of sheep and goat have been proved to sustain their welfare during stressful conditions such as thermal stress, the transition period. The use of flaxseed in the diet of lactating ewes under heat stress succeeds in increasing milk yield and ameliorating nutritional milk composition particularly in terms of milk fatty acid profile (Caroprese et al. 2011).

Lamb meat is valuable from a nutritional point of view for its high CLA content which can exert positive effects on human health (Schmid et al. 2006). The proportion of saturated and unsaturated fatty acid in meat from lambs subjected to different regimes highlights a better fatty acid profile in meat from artificially reared lambs from a nutritional and health promoting point of view. In particular, unsaturated fatty acids are considered hypolipidemic by reducing both plasma cholesterol and triglycerides, and a low intake of saturated fat as well as an increased polyunsaturated to saturated fatty acid ratio are associated with a lower risk of human coronary heart disease (Oriani et al. 2005). The addition of probiotics to milk replacer play a role in modulating the health status of lambs. Meat from artificially reared lamb fed milk replacer containing probiotic showed an improved fatty acid profile for human diet, in terms of higher CLA and lower SFA content (Santillo et al. 2011). 


\section{Conclusions}

Human induced climate changes, and subsequent global warming, are involving also European countries located within the temperate zone. As a result, the importance of sheep and goat farming is expected to increase gradually in comparison with cattle farming in both rural and industrialized countries. In fact, sheep and goats are more tolerant to climate extremes, in terms of production, reproduction, and resistance to diseases, and less competitive with humans for crops and grains than cattle. So that the role that sheep and goat farming are about to play is achieved in a fully sustainable way; the effort of research and the production world is invoked. It must aim to find feeding strategies and management practices for reducing emissions from sheep and goat farming, to identify dimensional and physical parameters, and management practices for sustaining flock welfare, and to raise the profitability of sheep and goat farming by reducing the impact of veterinary costs and increasing the commercial value of sheep and goat products.

Open Access This chapter is distributed under the terms of the Creative Commons Attribution Noncommercial License, which permits any noncommercial use, distribution, and reproduction in any medium, provided the original author(s) and source are credited.

\section{References}

Albenzio M, Santillo A, Caroprese M, Marino R, Centoducati P, Sevi A (2005) Effect of different ventilation regimens on ewe milk and Canestrato Pugliese cheese quality in summer. J Dairy Res 72:447-455

Amaral-Phillips DM, McGilliarg AD, Lindberg GL, Veenhuizen JJ, Yang JW (1993) Effects of decreased availability of glucose for dairy cows. J Dairy Sci 76:752-761

Beauchemin KA, Kreuzer M, O'Mara F, McAllister TA (2008) Nutritional management for enteric methane abatement: a review. Aust J Exp Agric 48:21-27

Bianchi L, Casoli C, Pauselli M, Budelli E, Caroli A, Bolla A, Duranti E (2004) Effect of somatic cell count and lactation stage on sheep milk quality. Ital J Anim Sci 3:147-156

Cannas A (2002) Feeding of lactating ewes. In: Pulina G (ed) Dairy sheep feeding and nutrition. Avenue Media, Bologna, pp 123-166

Caroprese M, Napolitano F, Albenzio M, Annicchiarico G, Muscio A, Sevi A (2006) Influence of gentling on lamb immune response and human-lamb interactions. Appl Anim Behav Sci 99:118-131

Caroprese M, Annicchiarico G, Schena L, Muscio A, Migliore R, Sevi A (2009) Influence of space allowance and housing conditions on the welfare, immune response and production performance of dairy ewes. J Dairy Res 76:66-73

Caroprese M, Albenzio M, Bruno A, Fedele V, Santillo A, Sevi A (2011) Effect of solar radiation and flaxseed supplementation on milk production and fatty acid profile of lactating ewes under high ambient temperature. J Dairy Sci 94:3856-3867

Caroprese M, Napolitano F, Boivin X, Albenzio M, Annicchairico G, Sevi A (2012) Development of affinity to the stockperson in lambs from two breeds. Physiol Behav 105:251-256

Costa MJRP, Siva RG, Souza RC (1992) Effect of air temperature and humidity on ingestive behaviour of sheep. Int J Biometeorol 36:218-222 
de Rancourt M, Fois N, Lavín MP, Tchakérian E, Vallerand F (2006) Mediterranean sheep and goats production: an uncertain future. Small Rumin Res 62:167-179

Fajardo-Lira CE, Nielsen SS (1998) Effect of psychotrophic microorganisms on the plasmin system in milk. J Dairy Sci 81:901-908

Fraser D (2008) Toward a global perspective on farm animal welfare. Appl Anim Behav Sci 113:330-339

Gibon A, Sibbald AR, Flamant C, Lhoste P, Revilla R, Rubino R, Sorensen JT (1999) Livestock farming systems research in Europe and its potential contribution for managing towards sustainability in livestock farming. Livest Prod Sci 61:121-137

Habeeb AAM, Marai IFM, Kamal TH (1992) Heat stress. In: Phillips C, Piggins D (eds) Farm animals and the environment. CAB International, Wallingford, pp 27-47

Hemsworth PH, Coleman GJ (1998) Human-livestock interactions: the stockperson and the productivity and welfare of intensively-farmed animals. Cab International, Oxon

Jones RB (1997) Fear and distress. In: Appleby MC, Hughes BO (eds) Animal welfare. CAB International, Wallingford, pp 75-87

Kume S, Kurihara M, Takahashi S, Shibata M, All T (1987) Effect of hot environmental temperature on major mineral balance in lactating cows. Jpn J Zootech Sci 58:764-770

Loretz C, Wechsler B, Hauser R, Rusch P (2004) A comparison of space requirements of horned and hornless goats at the feed barrier and in the lying area. Appl Anim behav Sci 87:275-283

Manrique E, Olaizola A, Bernues A, Revilla R (1996) Economic diversity of mountain sheep farms and complementarity strategies in land use. In: Proceedings of the international symposium on the optimal exploitation of marginal mediterranean areas by extensive ruminant production systems, Publ 83. EAAP, Thessaloniki, pp 61-66

NRC (1988) Nutrient requirements of dairy cattle, Update 1989. National Academy of Science, Washington, DC

Oriani G, MaioranoG FF, Di Cesare C, Manchisi A, Salvatori G (2005) Effect of age on fatty acid composition of Italian Merino suckling lambs. Meat Sci 71:557-562

Peacock C, Sherman DM (2010) Sustainable goat production-some global perspectives. Small Rumin Res 89:70-80

Ronchi B, Nardone A (2003) Contribution of organic farming to increase sustainability of mediterranean small ruminants livestock systems. Livest Prod Sci 80:17-31

Santillo A, Annicchiarico G, Caroprese M, Marino R, Sevi A, Albenzio M (2011) Probiotics supplementation influences growth and immune function of artificially reared lambs. Animal 6:339-345

Schmid A, Collomb M, Sieber R, Bee G (2006) Conjugated linoleic acid in meat and meat products: a review. Meat Sci 73:29-41

Sevi A, Massa S, Annicchiarico G, Dell'Aquila S, Muscio A (1999) Effect of stocking density on ewes milk yield, udder health and micro-environment. J Dairy Res 66:489-499

Sevi A, Muscio A, Casamassima D, Albenzio M (2000) Effects of litter treatment with paraformaldehyde on bacteriological, nutritional and renneting characteristics of ewes milk. Adv Food Sci 22:14-21

Sevi A, Annicchiarico G, Albenzio M, Taibi L, Muscio A, Dell'Aquila S (2001a) Exposure of solar radiation and feeding time and production of lactating ewes under high ambient temperature. J Dairy Sci 84:629-640

Sevi A, Taibi L, Albenzio M, Annicchiarico G, Muscio A (2001b) Airspace effects on the yield and quality of ewe milk. J Dairy Sci 84:2632-2640

Sevi A, Taibi L, Albenzio M, Muscio A, Dell'Aquila S, Napolitano F (2001c) Behavioral, adrenal, immune, and productive responses of lactating ewes to regrouping and relocation. J Dairy Sci 79:1457-1465

Sevi A, Albenzio M, Annicchiarico G, Caroprese M, Marino R, Taibi L (2002) Effects of ventilation regimen on the welfare and performance of lactating ewes in summer. $\mathrm{J}$ Anim Sci 80:2362-2372 
Sevi A, Albenzio M, Muscio A, Casamassima D, Centoducati P (2003a) Effects of litter management on airborne particulate in sheep houses and on the yield and quality of ewe milk. Livest Prod Sci 81:1-9

Sevi A, Taibi L, Albenzio M, Annicchiarico G, Marino R, Caroprese M (2003b) Influence of ventilation regimen on micro-environment and on ewe welfare and milk yield in summer. Ital J Anim Sci 2:197-212

Sevi A, Taibi L, Albenzio M, Caroprese M, Marino R, Muscio A (2003c) Ventilation effects on air quality and on the yield and quality of ewe milk in winter. J Dairy Sci 86:3881-3890

Sevi A, Albenzio M, Annicchiarico G, Caroprese M, Marino R, Santillo A (2006) Effects of dietary protein level on ewe milk yield and nitrogen utilization, and on air quality under different ventilation rates. J Dairy Res 73:197-206

Sevi A, Casamassima D, Pulina G, Pazzona A (2009) Factors of welfare reduction in dairy sheep and goats. Ital J Anim Sci 8:81-101

Tamminga S (1996) A review on environmental impacts of nutritional strategies in ruminants. J Anim Sci 74:3112-3124

Wilkerson VA, Casper DP, Mertens DR, Tyrell HF (1994) Evaluation of several methane producing equations for dairy cows. In: Aguilera JF (ed) Energy metabolism of farm animals. C.S.I.C, Granada, p 395, EAAP publ. no. 76 